\title{
Novel Solutions in Poverty Alleviation in Hungary, with Special Regard to Regional Differences
}

\author{
SIPOSNÉ NÁNDORI ESZTER, Ph.D. \\ ASSOCIATE PROFESSOR \\ UNIVERSITY OF MISKOLC \\ e-mail: stsne@uni-miskolc.hu
}

\begin{abstract}
SUMMARY
The paper examines Hungarian social innovations in the field of poverty. Besides describing their main features, it examines empirical linkages between the rate of social innovations and economic growth. It uses the database of the SozialMarie prize and its methodology includes graphs and Pearson's correlation. It concludes that the main target groups of the projects coincide with the groups most exposed to poverty. It also finds that economic growth and the rate of social innovations are not significantly related. This implies that more social activism would be needed to alleviate poverty in the less developed regions.
\end{abstract}

Keywords: social innovation, poverty, regional differences, SozialMarie

Journal of Economic Literature (JEL) codes: I3, O35

DOI: http://dx.doi.org/10.18096/TMP.2020.01.05

\section{INTRODUCTION}

The connection and relationship between economy and society have long been investigated and examined by researchers. Among other things, social innovations are good examples of the strong relationship between the two disciplines. They are created to promote the satisfaction of human needs of different levels (Kocziszky et al. 2017). Social innovations to fight against poverty are intended to satisfy the first-level human needs of the Maslow pyramid, including physiological needs like access to water, air, food, shelter, sleep, clothing or reproduction (King 2010).

The paper examines the quantitative and qualitative features of Hungarian social innovations in the field of poverty, homelessness and indebtedness between 2008 and 2019. As for quantitative aspects, the number of social innovations and their changes over time are examined. As far as the qualitative aspects are concerned, the target groups and the main activities of the above described social innovations are analyzed. It is examined whether the main target groups and activities of social innovations coincide with the groups most exposed to poverty. Moreover, the paper focuses on any regional differences in the number of social innovations in the field of poverty. Finally, the paper examines empirical linkages between the rate of social innovations and economic growth.

\section{LITERATURE REVIEW}

First I review the literature dealing with the groups most exposed to poverty in Hungary. Then, after a brief summary of social innovation definitions, I describe the details of SozialMarie, the oldest prize for social innovation in Europe.

\section{Groups most Exposed to Poverty}

The oldest data about poverty in Hungary - which were not really accurate yet - are from the 1930s. Sociographers called Hungary the country of "the 3 million beggars" at that time (Andorka 2006), which refers to a poverty rate of more than $30 \%$, since the country's population was around 8-9 million at that time (Dövényi et al. 2011).

In the period of socialism, data collection on the financial situation of the population became more accurate and regular. Although poverty did not officially exist in Hungary (it was considered taboo), information on income inequalities was already public at the time. During the period of socialism, there were no significant changes in the extent of poverty, but its composition changed significantly (Table 1). 
Table 1

Changes in the characteristics of the poor in the socialist era

\begin{tabular}{|l|c|c|}
\hline & Early 1960s & Late 1980s \\
\hline Area & villages & towns \\
\hline Economic sector & agriculture & industry \\
\hline Age group & pensioners & children \\
\hline Situation of the pensioners & poorer than the average & average \\
\hline
\end{tabular}

Source: own compilation based on Andorka (2006)

Migration due to urbanization led to a shift in the territorial concentration of poverty from villages to towns. Accordingly, by the end of the 1980s the social groups most affected by poverty were no longer physical workers in agriculture, but unskilled workers in factories in cities. There was also a change in the age composition of poverty: the situation of the old improved and thus reached the average level by the end of the period, while child poverty increased (Andorka 2006).

The political transition in 1990 increased the number of the poor. This is due, on the one hand, to the emergence and soaring rise in unemployment and, on the other hand, to accelerated inflation. Besides poverty, income inequalities also rose: the income share of the upper decile increased, while that of the lower decile and the middle class fell (Andorka 2006).

After the sharp increase of the extent and depth of poverty at the beginning of the 1990s due to the economic and political changes, the extent of poverty remained largely unchanged, although it slightly decreased at the end of the 1990s and at the beginning of the 2000s (Branyiczki \& Gábos 2018). Gábos and Szivós (2002) revealed the objective determinants of poverty. They examined the effects of the following indicators: age of the household head, his/her educational attainment, his/her labor market position (unemployed or inactive), his/her ethnic origin, type of dwelling and the number of household members. They concluded that the rate of those at risk of poverty was influenced by the following factors:
$>$ labor market position;

$>$ education attainment;

$>$ regional characteristics;

$>$ demographic factors.

Darvas and Tausz (2002) found that the number of children in the household, dwelling circumstances and Roma ethnicity were the most important risk factors of poverty.

The global economic crisis had social effects in Hungary earlier than in other countries (usually between 2009 and 2012) and therefore increased the extent of not only income poverty but also of income inequalities and of severe material deprivation. (Branyiczki \& Gábos 2018) Since 2012, however, the extent of income poverty and of severe material deprivation has fallen (Gábos et al. 2016). Györi (2017) found that since the millennium, the rate of the Roma and the rate of people with an over average number of children large families have increased among the homeless people. This implies that housing crisis, ethnic origin and having a large family are usually closely related, creating multiple disadvantages.

The rate of people living on begging, panhandling or collecting unwanted household items among the homeless increased significantly from 12\% in 2002 to 26\% by 2006. Since then, it has slightly fallen to below 20\% (Györi 2019). Györi (2019) measured the rate of beggars and the homeless people collected unwanted household items in some major towns of Hungary. Based on his data (Figure 1), no remarkable regional differences can be found. 


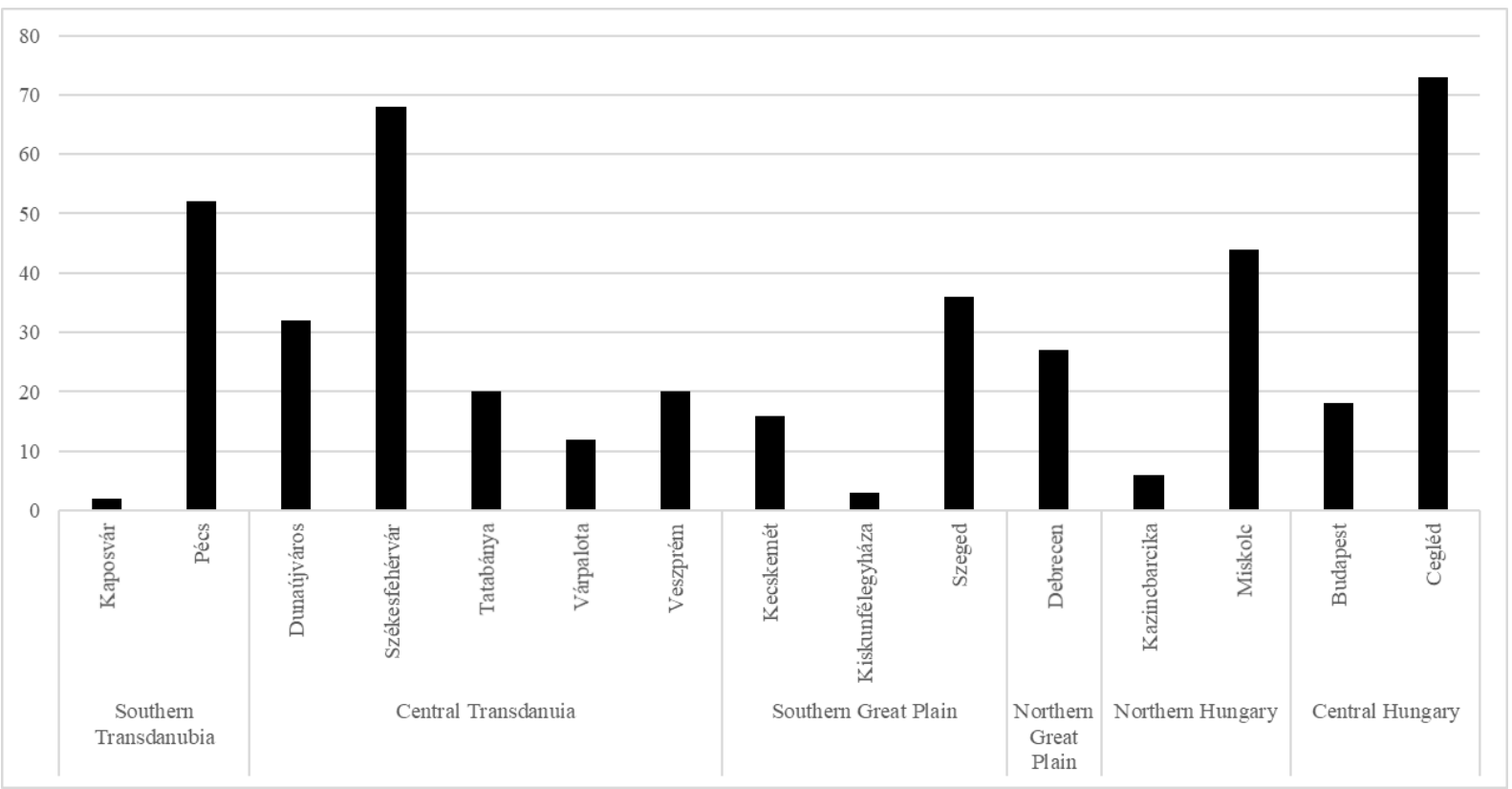

Source: own compilation based on Győri 2019, 35.

Figure 1. Rate of people living on begging, panhandling and collecting unwanted household items among homeless people in some towns in Hungary, 2018

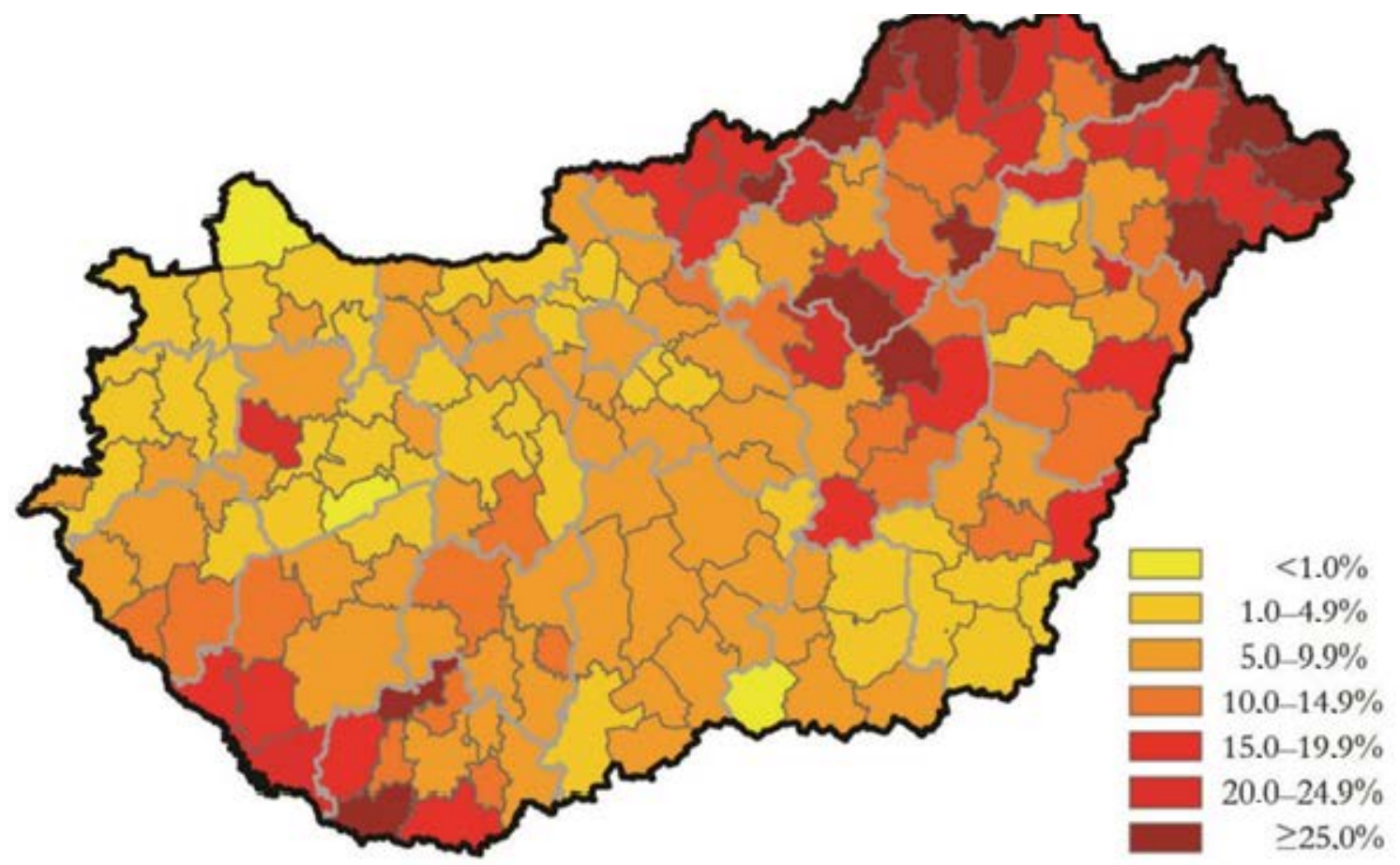

Source: Pénzes et al. (2018, p 18)

Figure 2. The ratio of the Roma population in districts of Hungary according to surveys of the University of Debrecen (2010-2013)

A further social group most exposed to poverty is the Roma population, which makes about $6-7 \%$ of the total Hungarian population. It is the poorest and most excluded part of the population. Their low education level and low employment level have led to their deep poverty (Bernát 2014). In 2012, TÁRKI conducted a survey that revealed that while $12 \%$ of the total Hungarian population lives below $60 \%$ of the median equivalized income, this rate is $76 \%$ for the Roma population (Gábos et al. 2013). The regional distribution of the Roma population is unequal in Hungary, with the highest concentrations in the 
northeastern and the southwestern parts of the country (see Figure 2).

Besides the homeless and Roma people, families with children also experience an increased risk of poverty and social exclusion. TÁRKI Household Monitor Survey revealed that at-risk-of-poverty levels have persisted among children since the beginning of the 1990s in Hungary (Gábos - Tóth 2019). The differences between households with at least one dependent child and households without any children by work intensity (referring to how much of their total work potential the adults worked during the past year), with some exceptions, point out that households with at least one dependent child have a greater probability of becoming poor (Figure 3).

\section{Social Innovations and SozialMarie}

The concept of innovation was first used by Schumpeter (1934) who defined its five types: production of new goods or goods with new quality; introduction of new methods of production or sales of a product; new markets; creation of new forms of organizations; new sources of supply of raw material or semi-finished goods. The concept of social innovation is newer and has no single definition. It was first mentioned by Drucken (1985), who drew attention to the importance of social innovations. Whyte (1987:45) defined social innovations as "social intentions to solving human problems”. G. Fekete (2015: 282) says that social innovation, on the one hand, may refer to the involvement of social resources to the economy (which is a new idea compared to the previous practices). On the other hand, it refers to new solutions elaborated and disseminated by innovative organizations with mainly social goals, aiming at satisfying social needs. The latter one practically incorporates the previous one. The current interpretation implies that an innovation is considered social when: it is driven by social value; the idea is at least partly derived from the civil society and social movements; new forms of social cooperation and new forms are used in its development and realization; it reacts to the society.

Kocziszky et al. (2017:16) define social innovations as giving “new or novel answers to a community's problems in order to increase the community's wellbeing”.

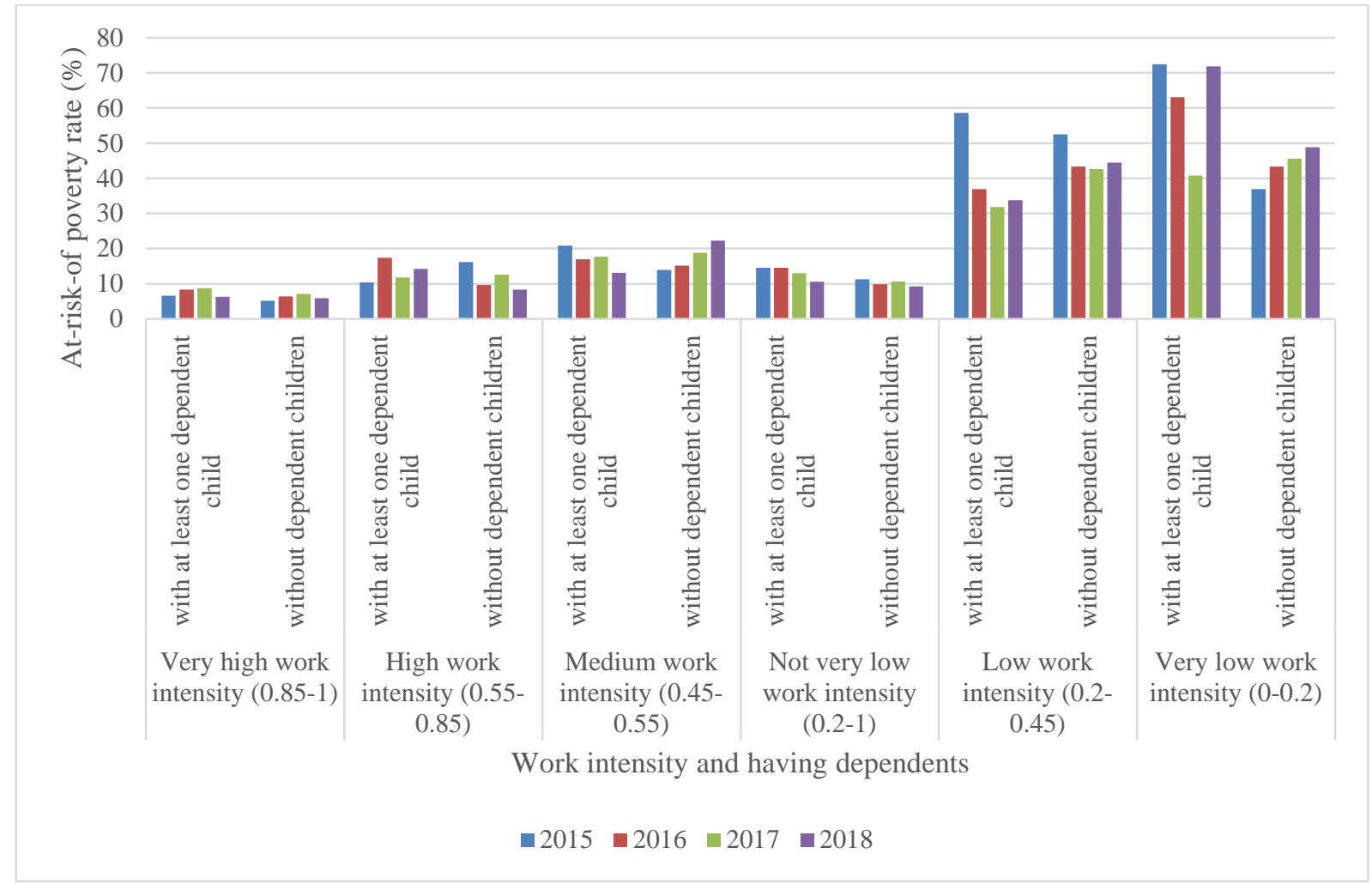

Source: own compilation based on Eurostat SILC database (https://ec.europa.eu/eurostat/web/income-and-livingconditions/data/database)

Figure 3. At-risk-of poverty rates of households with at least one dependent child and without any children by work intensity, 2015-2018 


\section{SozialMarie, Prize for Social Innovation}

SozialMarie is the oldest prize for social innovation in Europe and has honored 15 projects each year since 2005. Application for the prize is possible from Austria, Hungary, Czechia Republic, Croatia, Slovenia, Germany and Poland. The organizers of the prize use the following definition of social innovation:

"Social innovation drafts solutions to pressing social challenges. It provides room for new approaches, gives innovative answers and lays news paths. Social innovation either reacts to a new social question or it solves a known problem by a new practice. Action can be taken by the affected social group itself, it must in any case be appropriated and co-implemented by those concerned. In this manner, social innovation creates sustainable, exemplary solutions that inspire others." (SozialMarie. (n.d.))

The submitted projects are evaluated based on the following four criteria:

$>$ Innovation in the project idea: the novelty of the project can be the identification of a new social problem or a new way to solve an already known social problem;

$>$ Innovation in accessing target groups: projects that involve the target groups are evaluated more highly;

$>$ Innovation in implementation: the effectiveness of the projects are evaluated as well as the cooperation they can create among different groups;

$>$ Innovation in public perception: the extent to which the projects are integrated into the local and regional environment and their cooperation with other institutions is examined (SozialMarie. (n.d.)).

\section{HYPOTHESES, DATA AND METHODS}

The first hypothesis states that the most common target groups and activities of the innovative projects in the field of poverty coincide with the groups most exposed to poverty in Hungary nowadays, based on Györi (2017). This hypothesis implies that the main target groups of innovative projects are the Roma, the homeless and children.
My second hypothesis is that in the less developed regions (where per capita GDP is lower), the rate of social innovations in the field of poverty is higher because in these regions there is an increased need for poverty alleviation.

Hungarian social innovations aiming at the alleviation of poverty are examined based on the database of the SozialMarie prize. Up to October 2019, all of the submitted innovations between 2008 and 2019 were available at sozialmarie.org including their short description and their main characteristics. For this period, the database included 147 Hungarian projects in the field of poverty, homelessness and indebtedness.

The number, main activities, main target groups and regional characteristics of social innovations are analyzed with relative frequencies and graphs. The relationship between regional distribution and economic growth is tested with Pearson's correlation.

\section{MAIN FINDINGS}

\section{Number and Regional Distribution of Hungarian Social Innovations in the Field of Poverty, Homelessness and Indebtedness}

The main aim of this section is to describe the number and regional distribution of poverty- related social innovations to highlight whether there are any regional differences and to examine whether economic growth and the per capita rate of social innovations are related. As a result, the second hypothesis can be tested.

Between 2008 and 2012, the number of projects in the field of poverty, homelessness and indebtedness applying for the SozialMarie prize kept increasing, except for the year 2009, when no projects from Hungary applied for the prize in the field of poverty. The peak in the number of the examined projects was between 2012 and 2014. With the exception of a slight increase in 2017, the number has been decreasing since 2014. As for the number of the prizewinning projects, the best years were 2014 and 2017, when out of the three nominated projects in the given field, two were awarded each year (Figure 4). 


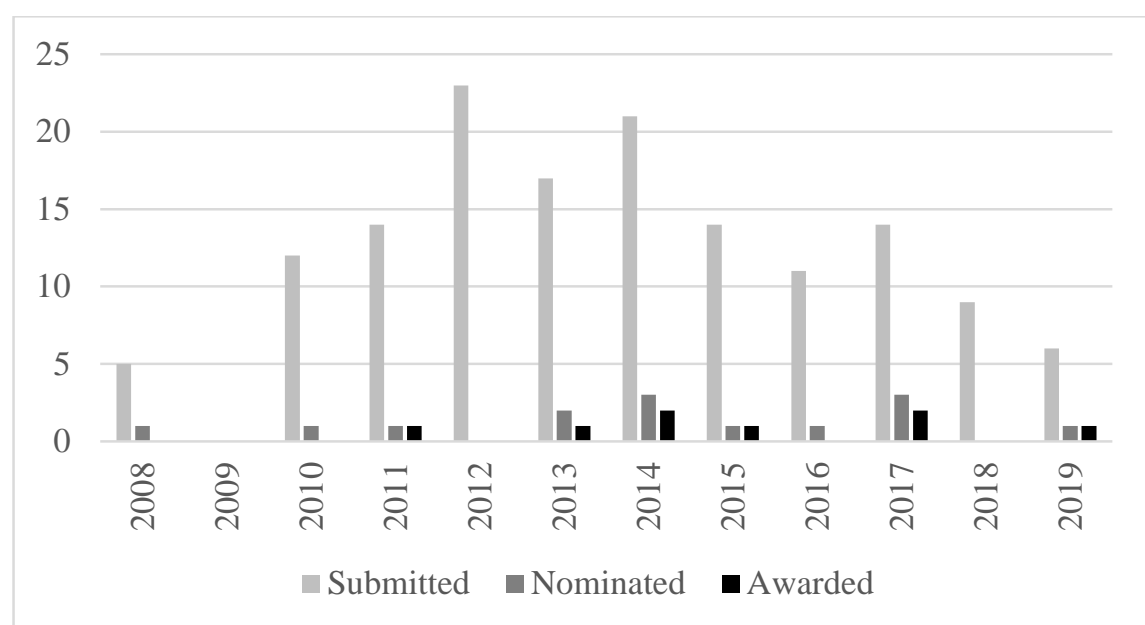

Source: own compilation and own calculation based on SozialMarie database

Figure 4. Number of awarded and submitted Hungarian projects in the field of poverty, homelessness and indebtedness for SozialMarie, 2008-2019

Table 2

Number of innovative projects in the field of poverty in the Hungarian regions, 2008-2019

\begin{tabular}{|c|c|c|c|c|c|c|c|c|}
\hline & 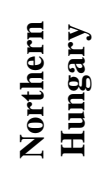 & 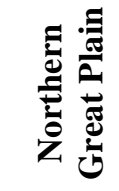 & 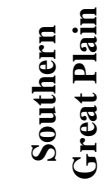 & 졸 & 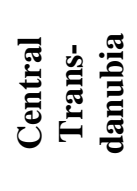 & 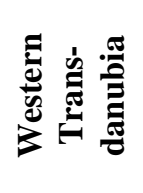 & 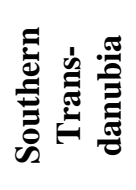 & 종 \\
\hline 2008 & 0 & 0 & 0 & 0 & 0 & 1 & 0 & 1 \\
\hline 2009 & 0 & 0 & 0 & 0 & 0 & 0 & 0 & 0 \\
\hline 2010 & 1 & 1 & 1 & 1 & 0 & 0 & 0 & 4 \\
\hline 2011 & 2 & 2 & 0 & 2 & 0 & 0 & 0 & 6 \\
\hline 2012 & 2 & 1 & 0 & 4 & 0 & 0 & 2 & 9 \\
\hline 2013 & 4 & 3 & 1 & 5 & 0 & 1 & 0 & 14 \\
\hline 2014 & 3 & 3 & 1 & 6 & 2 & 1 & 1 & 17 \\
\hline 2015 & 1 & 0 & 0 & 4 & 0 & 0 & 0 & 5 \\
\hline 2016 & 0 & 1 & 0 & 2 & 0 & 0 & 1 & 4 \\
\hline 2017 & 1 & 0 & 0 & 3 & 0 & 0 & 1 & 5 \\
\hline 2018 & 2 & 0 & 0 & 5 & 0 & 0 & 1 & 8 \\
\hline 2019 & 1 & 0 & 0 & 3 & 0 & 0 & 0 & 4 \\
\hline Total & 17 & 11 & 3 & 35 & 2 & 3 & 6 & 77 \\
\hline
\end{tabular}

Source: own compilation and own calculations based on the SozialMarie database

The regional distribution of the Hungarian innovative projects in the given field is analyzed based on the area of its activity. About half of the examined projects perform their activities throughout the country, therefore the analysis of the regional distribution is only possible for projects operating in a specific settlement/county/region of Hungary. Based on their regional distribution, it can be concluded that even though most of the innovative projects in the field of poverty, homelessness and indebtedness are found in the Central Hungarian region (Table 2), the Northern Hungary region is at the top of the list when their number is compared to the population. The rate of innovative projects is the lowest in the Southern Great Plain, Central Transdanubia and Western Transdanubia (Figure 5).

Social innovations in the field of poverty applied for SozialMarie from the Central Hungarian region between 2010 and 2019 every year. The same applies to the Northern Hungarian region, with the exception of 2016. Projects from Northern Great Plain were active mainly between 2010 and 2014 with the exception of Debrecen Bike Maffia, which applied for SozialMarie in 2016 from Debrecen (Northern Great Plain). Projects from Southern Transdanubia applied for SozialMarie between 2012 and 
2018. The fewest social innovations in the field of poverty could be found in Central Transdanubia, Western Transdanubia and the Southern Great Plain. Interestingly, almost all of the projects from these three regions applied for SozialMarie in 2013 and 2014.

As for the counties of Hungary, Budapest has a similar position to that of the Central Hungarian region, as the capital has a dominant role within the central region. Pest, the other county belonging to the Central Hungarian region, has much lower GDP per capita (less than half that of Budapest) and a slightly higher rate of social innovations. The county-level breakdown also reveals that the high rate of social innovations in the Northern Hungary region is due to Borsod-Abaúj-Zemplén County, which has 0.85 social innovations in the field of poverty per ten thousand inhabitants, while the rate is only 0.07 in Heves and 0.14 in Nógrád, the two other counties belonging to Northern Hungary. There are five counties where there were no social innovations in the field of poverty submitted in the examined period (Figure 6).

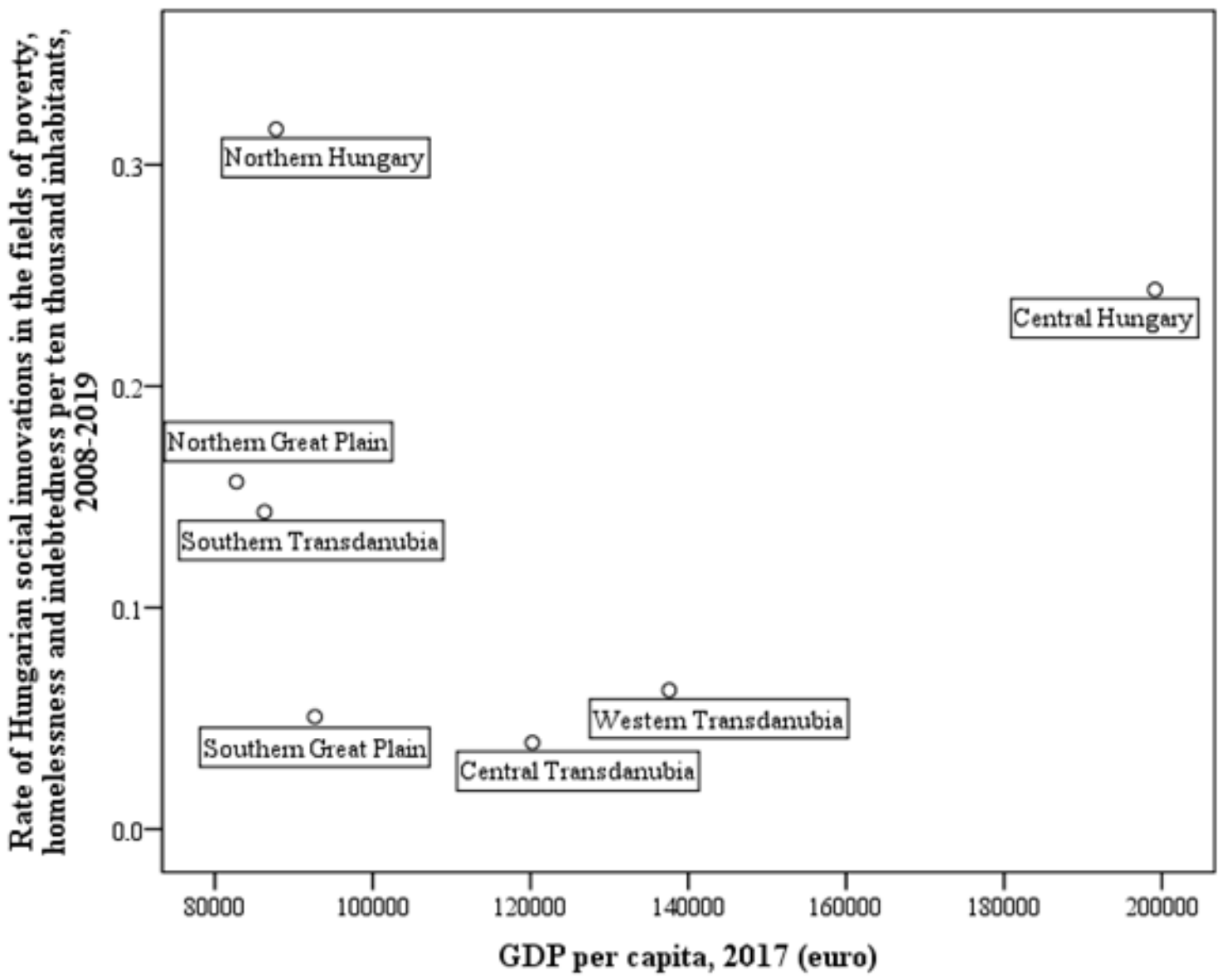

Source: own compilation and own calculations based on SozialMarie and HCSO databases

Figure 5. Relationship between the rate of Hungarian social innovations in the field of poverty, homelessness and indebtedness to ten thousand inhabitants and GDP per capita at the regional level 


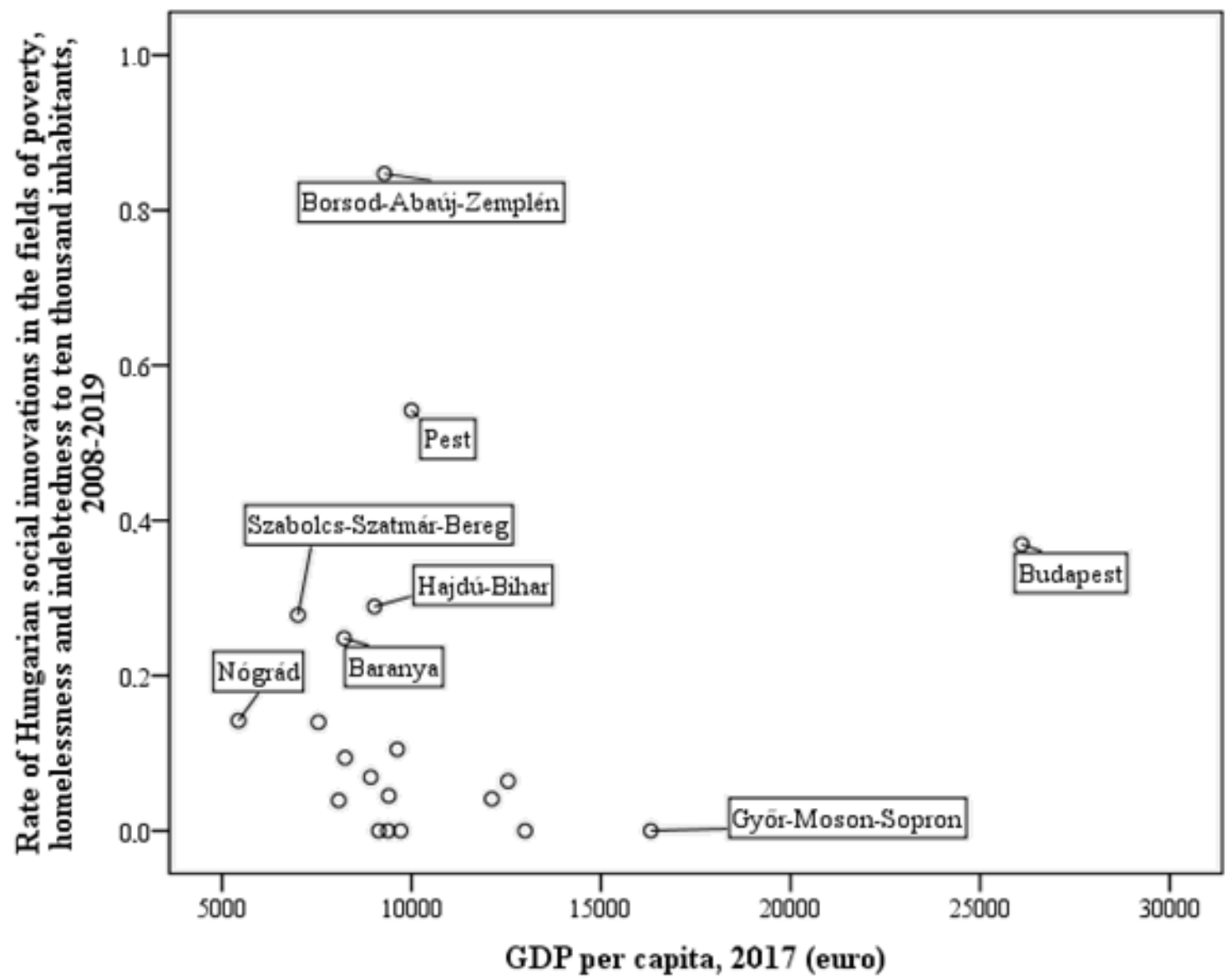

Source: own compilation and own calculations based on SozialMarie and HCSO databases

Figure 6. Relationship between the rate of Hungarian social innovations in the fields of poverty, homelessness and indebtedness to ten thousand inhabitants and GDP per capita at the county level

In order to test the hypothesis regarding the relationship between the rate of social innovations fighting poverty and economic growth, the number of such innovations per ten thousand inhabitants is calculated for the 20 NUTS3 level counties (including Budapest) and the 7 NUTS2 level regions of Hungary. To do so, the population data published by the Hungarian Central Statistical Office (HCSO) are used. The rates are then compared to the per capita GDP of 2017 (published by HCSO) and Pearson's correlation is calculated.

Table 3

Linear correlation between per capita GDP and the rate of Hungarian social innovations per ten thousand inhabitants

\begin{tabular}{|l|c|c|}
\hline & $\begin{array}{c}\text { Pearson } \\
\text { correlation }\end{array}$ & Sig. (2-tailed) \\
\hline $\begin{array}{l}\text { County } \\
\text { level data }\end{array}$ & 0.064 & 0.790 \\
\hline Regional data & 0.113 & 0.810 \\
\hline
\end{tabular}

Source: own compilation and own calculations based on SozialMarie and HCSO databases
Pearson's correlations (Table 3) show that the relationship is weak between the rate of social innovations and economic growth both for regional and county level data. The relationship is direct, implying that a higher level of economic growth is usually associated with higher rates of social innovation. The relationship is not significant, though. The second hypothesis is therefore rejected as in the less developed regions, the rate of social innovation in the field of poverty is not significantly higher.

\section{Activities and Target Groups of Hungarian Innovation in the Field of Poverty, Homelessness and Indebtedness}

To test the first hypothesis (about the relationship between the groups most exposed to poverty and the main target groups of the poverty related social innovations), the activities and the target groups of the social innovations in the field of poverty are examined.

Innovations against poverty aim at helping the poor in many fields. Children are the main target group for innovations (17\% of the examined innovations), but projects often focus on the homeless, the Roma and ill and 
disabled people. Only a small part of the projects aim at helping the elderly and immigrants (Figure 7).

The activities of the examined social innovations often correlate with the target groups. Twelve percent of the projects provide housing for the poor and another 12 percent provide education. Projects in the field of housing aim at helping the homeless, while projects in the field of education mainly aim at helping children and youths. Distributing food to poor people, which contributes to the satisfaction of a basic human need, accounts for $11 \%$ of the activities of the projects. Sensitization (making the members of the population more sensitive to social problems) is also a common activity (9\%), but usually in conjunction with other activities. Involvement of the target group is also an important element of some (8\%) of the projects, which may be partly due to the fact that this is a criterion of the evaluation of the prize. Providing assistance for the poor (6\%) and development in the field of health (6\%) are also listed among the relevant projects. Other targets are the increase of employment (5\%), giving support for underdeveloped regions (3\%) environmental protection (3\%) of the projects and help people involving animals (2\%) of the cases (Table 4).

The first hypothesis therefore is failed to be rejected, as the most common target groups (the Roma, the homeless and children) and activities (providing housing, education and food) of the innovative projects against poverty coincide with the groups most exposed to poverty in Hungary.

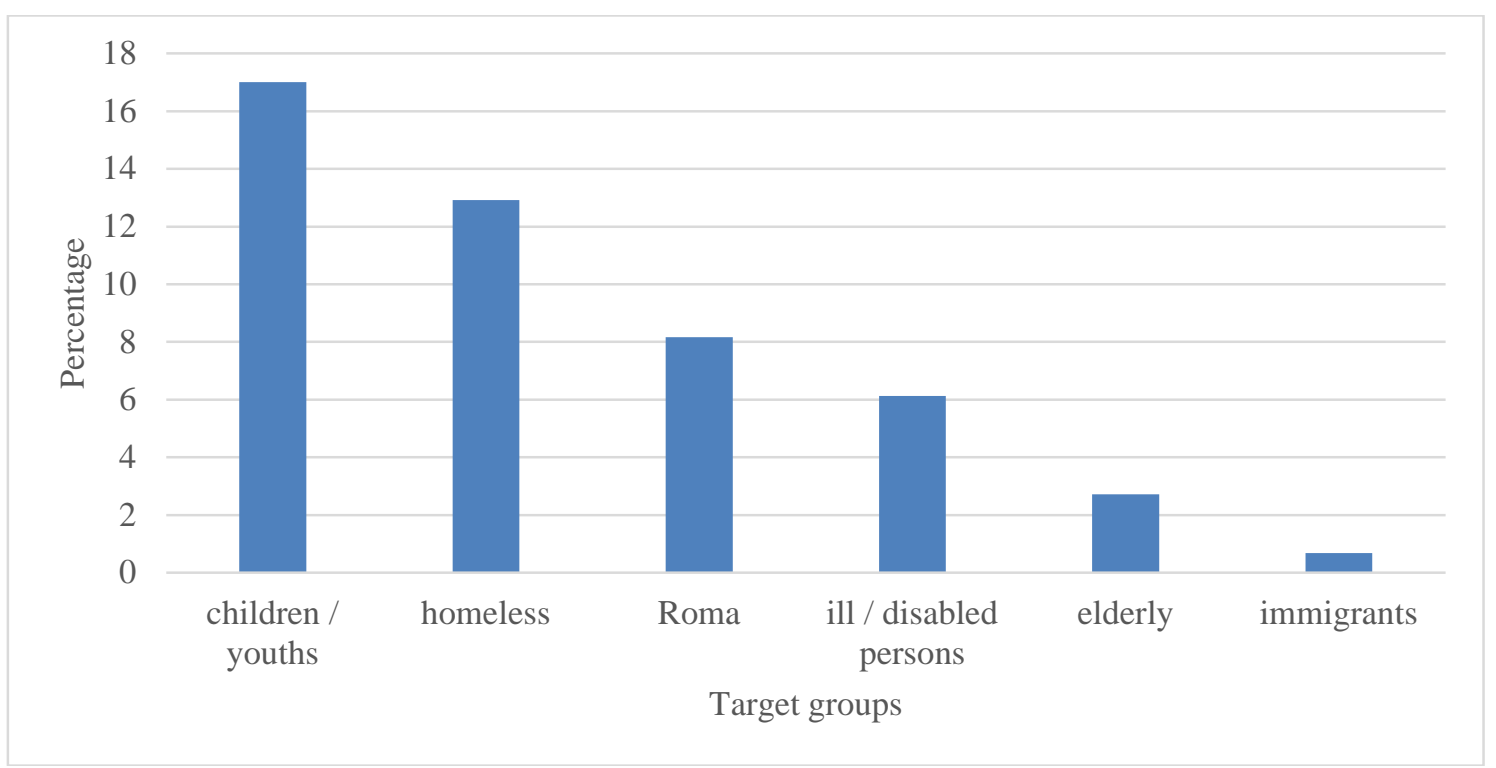

Source: own compilation and own calculation based on SozialMarie database

Figure 7. Most common target groups of Hungarian social innovations created to help the poor, 2008-2019

Table 4

Main activities of the Hungarian social innovations created to help the poor, 2008-2019

\begin{tabular}{|l|c|}
\hline Activity & Relative frequency \\
\hline Housing & 12 \\
\hline Education & 12 \\
\hline Food distribution & 11 \\
\hline Sensitization & 9 \\
\hline Involvement of the target group & 8 \\
\hline Assistance & 6 \\
\hline Development in the field of health & 5 \\
\hline Employment & 5 \\
\hline Regional development & 3 \\
\hline Environmental protection & 2 \\
\hline Involving animals to help people & 2 \\
\hline
\end{tabular}

Source: own compilation and own calculations based on SozialMarie database 


\section{Some Examples of Successful Social Innovations in the Field of Poverty in Hungary}

In this section, I describe two examples of innovative social projects fighting against poverty: one ("When is the time to act if not now?”) from the most developed Central Hungarian region and the other one from a least developed region.

\section{“When is the time to act if not now?"}

The project called " "When is the time to act if not now?' Participatory action research about housing movements in Budapest” received a 2000 euro prize from SozialMarie in 2017.

The project seeks to help resolve the housing crisis in Hungary and therefore to contribute to the satisfaction of the basic human need of shelter. It is carried out by gathering the "best practices" of the good old days. It focuses on the examples of mobilizing people to help those living in shelters or in the streets in the past (Csécsei et al. 2017).

As a result, a mobile exhibition has been created, the final location of which wasin Kassák Museum, Budapest. Moreover, some workshops have also been organized to publish the results. The good examples are intended to inspire struggles for housing today and in the future.

The project is organized by the School of Public Life. The need for this research emerged in 2009, when researchers of the School, taking part in the foundation of the "The City is for All” (A Város Mindenkié) advocacy group, realized how difficult it was to find examples of the struggles for rights of homeless people or people living in housing poverty. They believed that Hungarian housing activists would need good examples, like the example of their colleagues in the United States. Their good practices could be adopted in Hungary to solve current problems. The advocacy group has become a movement by now, cooperating with other organizations to find system-level solutions for housing problems.

The project "When is the time to act if not now?" was realized between January 2015 and July 2016 and involved two trained researchers and nine persons living in housing poverty. It therefore realized the principle of the involvement of the target group in the project. In the first twelve months, participants were trained and the data collection and data analysis were carried out. From January to July 2016, dissemination was carried out: the gathered materials were exhibited in several social institutions and community centers.

The project aimed at making a difference in four different areas:

$>$ It aimed at developing the researchers' skills;

$>$ It tried to deliver the message of the project to as many individuals living in housing poverty as possible;

$>$ It also aimed at making the members of the whole population, including those who can make a different in poverty alleviation, more sensitive to and aware of the housing crisis in Hungary;

$>$ It is to call the attention of the academics to pay more attention on research methods that involve the target group in the implementation process. (www.sozialmarie.org)

\section{“Steps For István akna”}

The project called "Steps for István akna" was nominated for the SozialMarie prize in 2016. The project 'Small Steps for István akna', implemented between October 12014 and November 30 2015, aimed to develop István akna, one of the most underdeveloped parts of Pécs, the capital of Southern Transdanubia. This district, situated about six miles away from downtown Pécs, is in a disadvantaged position for multiple reasons. The apartments there are in poor condition and public transportation does not work properly, which makes health care and appropriate education hardly available for the bulk of its population. For many years, the primary goal of the municipality of Pécs was to eliminate this district. However, due to the fact that this is difficult to implement (because of the low number of state-owned homes or low willingness to move), the municipality has involved the development of the district into the development plans of the city (SozialMarie. (n.d.).

As the proportion of children in the population is higher than the average here, the project seeks to take the first steps to lift poor people out of poverty by developing poor children's skills (www.sozialmarie.org).Duncan et al. (2011) conclude that childhood poverty has substantial effects on the adult labor market success, since they found that poverty early in childhood has harmful effects on adult earnings and work hours. Unicef concludes that malnutrition and poor hygiene practices often accompanying poverty prevent the children's healthy development. (Unicef (n.d.) Early development (ages 0-5) has a goal to minimize and eliminate these gaps. Within the framework of the project between 2014 and 2015, the early development of 33 toddlers (more than $60 \%$ of all the toddles living in István akna) was realized with individual development plans. In the framework of the project, action days and baby-mother days were organized which, besides helping the children's early development, drew the parents' attention to how to ensure the healthy development of their children.

The project was realized with the cooperation of the Roma Education Fund, which provided a significantfinancial help (EUR 30,000). Besides the Fund, the municipality of Pécs also helped the project by elaborating and implementing a comprehensible and integrated development plan. After 2015, however, because of the lack of the necessary financial resources, the project was temporarily cancelled and is unable to restart its operation without further investments. (SozialMarie. (n.d.) 


\section{CONCLUSION}

In the last dozen years, many innovative projects were established in Hungary in the field of poverty, which is well reflected by the fact that a total of 147 Hungarian projects fighting for the alleviation of poverty applied for the SozialMarie prize between 2008 and 2019. The main target groups of these projects are children, the homeless, Roma, the disabled, the elderly, and immigrants. The most common target groups of the projects well reflect the composition of the most disadvantaged people in Hungary. Research on poverty has revealed that the number of children, housing conditions and Roma minority are risk factors of poverty (Darvas \& Tausz 2002). The three factors that have become strongly associated with poverty since 2000, namely belonging to the Roma minority, having a large family, and living without shelter (Györi 2017) also coincide with the most common target groups of the examined social innovations.

In conjunction with the target groups, the most common activities of innovative projects are providing shelter, food, or education and the sensitization of the society. Many projects focus on the involvement of the target group. For instance, the project "When is the time to act if not now?", described above in detail, enhances the awareness of the general public to the housing crisis in Hungary and highlights the importance of providing shelter for everyone.

Analysis using county level and regional data revealed that the highest number of social innovations in the field of poverty can be found in the capital and in the Central Hungarian region. The proportion of the examined social innovations compared to the population, however, is the highest in the Northern Hungary region, one of the most underdeveloped regions of Hungary. In the other Hungarian regions with similarly low per capita GDP (Northern Great Plain, Southern Transdanubia and Southern Great Plain), however, the proportion of such social innovations is much lower. The project "Steps for István akna” is a project from Southern Transdanubia, which, unfortunately, has not been able to perform its activity since 2015 because of the lack of the necessary financial resources. It can be concluded that in the less developed regions of Hungary, more social activism would be needed. More innovative projects or the adaption of existing social innovations could contribute to the alleviation of poverty.

\section{Acknowledgement}

This research was supported by the project no. EFOP-3.6.2-16-2017-00007, titled Aspects on the development of intelligent, sustainable and inclusive society: social, technological, innovation networks in employment and digital economy. The project has been supported by the European Union, co-financed by the European Social Fund and the budget of Hungary.

\section{REFERENCES}

ANDORKA, R. (2006): Bevezetés a szociológiába (Introduction to Sociology). Osiris Kiadó, Budapest.

BERNÁT, ANIKÓ (2014): Leszakadóban: a romák társadalmi helyzete a mai Magyarországon (Falling behind: social position of the Roma in Hungary today). In: Kolosi Tamás \& Tóth István György (2014): Társadalmi riport 2014. TÁRKI Társadalmi Kutató Intézet. pp. 246-264.

BRANYICZKI, RÉKA \& GÁBOS, ANDRÁS (2018): A szegénység dinamikája a válság időszakában Magyarországon (Dynamics of Poverty During the Crisis in Hungary). In: Kolosi Tamás \& Tóth István György (2018): Társadalmi Riport 2018. TÁRKI Társadalmi Kutató Intézet. pp. 125-143.

CSÉCSEI, ILONA, CSENGEI, ANDREA, DÓSA, MARIANN, KLEINER, IMRE, PALOTAI, MAGDOLNA, SZAKMÁRY, IBOLYA TÜNDE, SZIRÁKI, ZOLTÁN, SZOMBATHY, KÁROLY, TOMPA, ISTVÁN, UDVARHELYI, ÉVA TESSZA \& WITTMANN, NÁNDOR (2017): Lakhatási mozgalmak Magyarországon a XX. században (Housing Movements in Hungary in the 20th Century). KOVÁSZ - 2017. spring-winter, pp. 65-81.

DARVAS, ÁGNES \& TAUSZ, KATALIN (2002): A gyermekek szegénysége (Children’s Poverty). Szociológiai Szemle, 4: pp. 95-120.

DÖVÉNYI, ZOLTÁN, KOCSIS KÁROLY \& TÓTH, JÓZSEF (2011): Népesedési jellemzők (Demographic characteristics). In: Kocsis Károly \& Schweitzer Ferenc (eds.): Magyarország térképekben. Magyar Tudományos Akadémia Földrajztudományi Kutatóintézet, Budapest. 
DUNCAN, GREG J., MAGNUSON, KATHERINE, KALIL, ARIEL \& ZIOL-GUEST, KATHLEEN (2012): The Importance of Early Childhood Poverty. Social Indicators Research, 108 (1) pp. 87-98. https://doi.org/10.1007/s11205-011-9867-9

DRUCKER, PETER (1985): Innovation and Entrepreneurship. New York: Harper \& Row. https://doi.org/10.1002/npr.4040050112

G. FEKETE, ÉVA (2015): Társadalmi innovációk a helyi foglalkoztatásban (Social innovations in local employment). In: Veresné Somosi Mariann, Lipták Katalin (eds.): „Mérleg és Kihívások” IX. Nemzetközi Tudományos Konferencia, 274-287.Gábos A. \& Szivós P. (2002): A jövedelmi szegénység alakulása, a gyermekes családok helyzete (Evaluation of Income Poverty, Conditions of Families with Children). In: Kolosi Tamás \& Tóth István György (2002): Társadalmi Riport 2002. TÁRKI Társadalmi Kutató Intézet Budapest: TÁRKI. pp. 42-59.

GÁBOS, ANDRÁS, SZIVÓS, PÉTER \& TÁTRAI, ANNAMÁRIA (2013): Szegénység és társadalmi kirekesztés Magyarországon, 2000-2012. (Poverty and social exclusion in Hungary, 2000-2012.) In: Szivós P. - Tóth I. Gy. (eds.).: Egyenlőtlenség és polarizálódás a magyar társadalomban. TÁRKI Monitor Jelentések 2012, Budapest: TÁRKI. http://www.tarki.hu/hu/research/hm/monitor2012_teljes.pdf Last download: April 15, 2020

GÁBOS, ANDRÁS, TÁTRAI, ANNAMÁRIA, B. KIS, ANNA \& SZIVÓS, PÉTER (2016): Anyagi depriváció Magyarországon, 2009-2015 (Material Deprivation in Hungary, 2009-2015). In: Kolosi Tamás \& Tóth István György (eds.) Társadalmi Riport 2016., pp. 130-150.

GÁBOS, ANDRÁS \& TÓTH, ISTVÁN GYÖRGY (2019): Gyermekek helyzete a gazdasági válság idején és utána. Esély 2019/3. pp. 5-25.

GYÖRI, PÉTER (2017): Hajléktalanság - romák - gyermekszegénység (Homelessness - Roma - Child Poverty). Esély, 2017/4. pp. 17-44.

GYÖRI, PÉTER (2019): A hajléktalanvilág peremén. Kolduló és kukázó hajléktalan emberek. (On the edge of homelessness: Begging and rag and bone homeless persons) Esély, 2019/2. pp. 31-65.

KING, PAUL W. (2010): Climbing Maslow’s Pyramid. Troubador Publishing

KOCZISZKY, GYÖRGY, VERESNÉ SOMOSI, MARIANN \& BALATON, KÁROLY (2017): A társadalmi innováció vizsgálatának tapasztalatai és fejlesztési lehetősége (Experiences of the Examination of Social Innovations and Their Development Possiblities). Vezetéstudomány, 48 (6-7) pp. 15-19. https://doi.org/10.14267/VEZTUD.2017.06.02

PÉNZES, JÁNOS, TÁTRAI, PATRIK \& PÁSZTOR, ISTVÁN ZOLTÁN (2018): A roma népesség területi megoszlásának változása Magyarországon az elmúlt évtizedekben (Changes in the Spatial Distribution of the Roma Population in Hungary During the Last Decades). Területi Statisztika, 58 (1): pp. 3-26 https://doi.org/10.15196/TS580101

SCHUMPETER, JOSEPH ALOIS (1934): The theory of economic development: an inquiry into profits, capital, credit, interest and the business cycle, Harvard Economic Studies, Vol. 46, Harvard College, Cambridge, MA. https://doi.org/10.1080/00343404.2017.1278975

SOZIALMARIE. (n.d.) website, SozialMarie Prize for Social Innovation. https://www.sozialmarie.org

UNICEF (n.d.) website, Kérdések és válaszok a korai fejlesztésről (Questions and answers about early development). https://unicef.hu/korai-fejlesztes

WHYTE, W. F. (1987): Social Inventions for Solving Human Problems. Clinical Sociology Review, 5 (1) $45-$ 63. https://doi.org/10.2307/2095038 